\title{
Impact of changing ecophysiological conditions in blood urea levels of freshwater fish Wallago attu
}

\author{
Sudhish Chandra \\ P.G. Department of Zoology, B.S.N.V. College, Lucknow-226001, INDIA \\ E-mail : sudhish1953@gmail.com
}

\begin{abstract}
Definite cyclic variations were observed in blood urea levels of freshwater catfish Wallago attu. The maximal mean blood urea level $(8.44 \pm 1.96 \mathrm{mg} / 100 \mathrm{ml})$ was noted in the month of June while minimal level in December, revealing a difference of $65.87 \%$ between the two levels. Seasonal alterations observed here in $W$. altu were correlated with ecophysiological factors like temperature, food availability, body metabolism, breeding cycle and hormonal changes which have been essentially found to be involved in fish life.
\end{abstract}

Keywords : Wallago attu, Blood urea, Spawning, Seasonal, Temperature

\section{INTRODUCTION}

Variations in fish environment trigger a series of characteristic physiological changes within the fish body. Successive seasonal events are known to occur in a regular seasonal progression and even under constant conditions (Dunlop et al., 2004). Fish normally experiencing seasonal changes in their environment are subjected to marked changes in their biochemical blood constituents to maintain normal functioning of body. Studies on biochemical constituents of blood make it possible to understand the delicate physiological status of fish under varying situations. Urea is one of the endogenous degradation products resulting from protein metabolism and plays an important role in the physiology of fishes. The present observations are on the impact of changing ecophysiological conditions in blood urea levels of freshwater catfish Wallago attu, a common food fish of this area.

\section{MATERIALS AND METHODS}

The method of collection, transportation and maintenance of fishes in the laboratory were the same as described earlier (Tandon and Chandra,1977). Only healthy fishes in the weight range of 350-400 grams were selected for the purpose. Fish were taken out of the aquarium with least stress, blotted with a clean turkish towel, their caudal end amputated and flowing blood from caudal vessels was collected in a clean vial having anticoagulant potassium citrate, was mixed gently and kept in refrigerator until analysed. Blood urea level was determined following the method of Natelson (1957), using Bausch and Lomb spectronic-20 spectrophotometer at $480 \mu \mathrm{m}$.

\section{RESULTS}

Blood urea levels in the fish $W$. attu fluctuated during different months of the year. The maximal mean blood urea level $(8.44 \pm 1.96 \mathrm{mg} / 100 \mathrm{ml})$ was observed in the month of June, while the minimal level $(2.88 \pm 0.80 \mathrm{mg} / 100 \mathrm{ml})$ was obtained in the month of December. Thus the difference between the maximal and minimal mean values was found to be $65.87 \%$. Blood urea levels obtained for the twelve months are depicted in Table 1 . The level started declining from its peak level and continued to fall upto the month of December. Thereafter blood urea level started gradually rising and continued upto the month of June, reaching its peak level. It was interesting to note that the rate of decrease in blood urea levels during successive postspawning months were lower than the rate of increase in its level during successive prespawning months. Statistically the values obtained for the months of November, December, January and February were highly significant $(\mathrm{P}<0.05)$, while the values for March, September and October were significant $(\mathrm{P}<0.05)$ versus the blood urea level of $W$. attu in the month of June.

\section{DISCUSSION}

Fishes normally experience successive seasonal events which are known to occur in a regular seasonal progression, may have evolved some physiological adjustments which allowed them to maintain normal functioning of body (Gordon, 1972). Biochemical changes occurring in fish are primarily due to the shift in the body metabolism and utilization of organic reserves, yielding excess energy to compensate the changed ecophysiological situations. Due to everchanging aquatic 
conditions the fishes are prone to exhibit effective variations in the blood composition (Shafi,2000). Higher blood urea levels observed during spawning period in $W$. attu clearly indicated enhanced hormonal and metabolic activity, greatly utilized protein contents, besides lipid in formation of sex products. Similar observations in blood urea and related biochemical constituents have been reported (Idler and Tsuyuki, 1958., Robertson et al., 1961, Hutton, 1968, Tandon and Chandra, 1977, 1980, Chandra, $1985,1986,1995)$. The occurrence of many substances is not constant, they change with maturation cycle of fish

Table 1. Blood urea levels in W. attu during different months of the year.

\begin{tabular}{lcc}
\hline Month & No. of Fish & $\begin{array}{c}\text { Blood urea levels ml } \\
\text { (Mean } \pm \text { SD) }\end{array}$ \\
\hline January & 20 & $3.10 \pm 1.67$ \\
February & 26 & $3.38 \pm 0.93$ \\
March & 32 & $4.65 \pm 0.68$ \\
April & 28 & $5.80 \pm 0.95$ \\
May & 33 & $7.91 \pm 1.33$ \\
June & 34 & $8.44 \pm 1.96$ \\
July & 38 & $6.80 \pm 1.40$ \\
August & 29 & $6.00 \pm 0.82$ \\
September & 31 & $5.22 \pm 1.10$ \\
October & 29 & $4.45 \pm 0.86$ \\
November & 28 & $3.68 \pm 0.76$ \\
December & 25 & $2.88 \pm 0.80$ \\
\hline
\end{tabular}

(Saxena, 2000). Lipid and protein contents from liver and muscle are known to contribute significantly in gonadial development. (Singh and Singh, 1983, Kinne, 1995). Since the reproductive cycle in teleosts is directly related to environmental conditions of surrounding water, which bears direct concern with the seasonal variations (Lehri, 1968), may trigger several neuroendocrine mechanism to regulate physiological changes. Correlative cyclic changes in the pituitary gland and gonads in relation to breeding behaviour have been reported in freshwater fishes (Sathyenishan, 1969, Dhanze et al., 2001).

Blood urea level in W. attu started gradually declining after spawning and continued to fall through postspawning months. After spawning fish appeared to become exhausted due to vigorous sexual activities and most of the reserve material of body utilized, leading to resting phase. Gradual retardation in food availability further slowed down metabolism resulting to lowering blood urea levels. During diminished feeding conditions mobilization of some energy substances to meet the changing situation have been described as a part of integrated response in fishes (Bonga, 1997). Pond dwelling teleost fishes are known to gradually undergo compensatory biochemical adaptation to changing ecological temperature (Eckert and Randall,1987) and it was apparent during winter months showing retarted blood urea levels in W. attu. The onset of better environmental conditions due to gradual rise in temperature lead to better availability of protein rich food, appeared to increase the metabolic activities of fish resulting gradual increase in blood urea levels during prespawning months. Food intake is one of the most important factor regulating the level of metabolism which integrates many physiological processes (Bhavan and Geraldine,2000). Such ecological situations provide an opportunity to fish for rejuvenation and preparation for next breeding. Shafi (2000) mentioned that the seasonal rise and fall of temperature of the freshwaters are related not only to the availability of natural food, rather there is impact also on the degree of conversion of the ingested food. Thus variations in blood urea levels of $W$. attu appear to be related to several ecophysiological factors individually and collectively such as activity of the fish, sexual cycle, hormonal. activity, temperature and availability of food material etc. in ecological niche of the fish.

\section{REFERENCES}

Bhavan, P.S. and Geraldine, P. (2000). Aberrations in various parameters of bioenergetics in the prawn $M$. malcomsonri following exposure to endosulfan. Aquacult., 1: 141-152.

Bonga, S.E.W. (1997). The stress response in fish. Physiol. Rev. $77: 3$

Chandra, S. (1985). Sex related variations in serum cholesterol levels of some freshwater fishes (Cypriniformes). J.Curr. Biosci., 2: 51-54.

Chandra, S. (1986). Cyclic changes in blood urea levels of freshwater catfish Rita rita. Proc. Nat. Symp. Fish \& Environ. 107-109.

Chandra, S. (1995). Cyclic changes in total serum protein levels of freshwater catfish Rita rita. Biol. Memoirs, 21: 73-75.

Dhanze, J.R., Sharma,I. and Dhanze, R. (2001). Seasonal variations in the histology of pituitary gland of Tor putitora in relation to its breeding behaviour. Aquacult., 2: 45-53.

Dunlop, J.C., Loros, J.J. and Decoursey, P.J. (2004). Chronobiology - biological time keeping. Sinaur Associates Inc. Pub. Sunderland, Massachusetts, U.S.A.

Eckert, R. and Randall, D. (1987). Animal PhysiologyMechanism and Adaptations. 2nd ed. CBS Pub.\&Distri., Delhi

Gordon, M.S. (1972). Animal physiology, The Mc Millan Co., New York.

Hutton, K.E. (1968). Characteristics of the blood of adult pink salmon at three stages of maturity. Fish. Bull.66: 195-202.

Idler, D.R. and Tsuyuki, H. (1958). Biochemical studies on physical measurement, plasma cholesterol and electrolyte levels. Can. J. Biochem. Physiol., 36: 783-791.

Kinne, E.D. (1995). The effect of pollution on reproduction in fishes, Rev. Fish. Biol. Fish., 5: 52-96.

Lehri, G.K. (1968). Cyclical changes in the ovary of the catfish Clarias batrachus. Acta. Anat. 69: 105-124.

Natelson, S. (1957). Microtechniques of clinical chemistry for the routine laboratory. C.G. Thomas, Spring. 
Robertson, O.H., Krupp, M.A., Favour, C.B., Hane, S. and Thomas, S.F. (1961).Physiological changes occurring in the blood of the pacific salmon Onchorhynchus tschwytscha, accompanying sexual maturation and spawning. Endocrinol. 68: 733-746.

Sathyenesan, A. G. (1969). Correlative cycling changes in the pituitary and gonad of Mystus seenghaea and Barbus stigma. J. Zool. Soc. India, 12: 175-190.

Saxena, A. (2000). Biochemical changes in liver and muscle of Channa gachua during reproductive cycle. Aquacult, 1: 5156.

Shafi, S.M. (2000). Modern Ichthyology, Inter India Pub., New Delhi.
Singh, L.L. and Singh, T.P. (1983). Annual changes in the total gonadotrophic potency in relation to gonadial activity in freshwater catfish Clarias batrachus. J. Interdiscipl. Cycle Res. 14: 227-239.

Tandon, R.S. and Chandra, S. (1977). Cyclic changes in blood urea levels of freshwater catfish Clarias batrachus. Z. Tierphysiol. Tierernah. u. Futtermittelkde. 38: 211-214.

Tandon, R.S. and Chandra. S. (1980). Ecophysiology of Fishes: Changes in serum glutamic oxalacetic transaminase levels of freshwater fish Wallago attu, during varied conditions of life. J. Adv. Zool., 1: 28-32. 